\title{
Analysis of a Reverse Logistics Network Model of Electrical and Electronic Products
}

\author{
Jiawei Wang ${ }^{1, a}$ \\ ${ }^{1}$ North China Electric Power University, Beijing 102206, China \\ a1462897130@qq.com
}

Keywords: electrical and electronic product; reverse logistics; network model

\begin{abstract}
With the rapid development of science, technology and economy, electrical and electronic products have already been closely related to people' s work and life. However, a large amount of waste of electrical and electronic products also warrants our attention. To truly realize nonhazardous treatment of waste of electrical and electronic products, China needs to build a perfect reverse logistics network. For this end, in this paper, we make a specific analysis of the reverse logistics network model of electrical and electronic products. Hopefully, our study could bring some inspiration to the construction of this network.
\end{abstract}

\section{Introduction}

At present, China is facing serious resource and environmental pressure. This is also the reason why our government advocates building a resource-conserving and environment-friendly society. To put this society into reality, we must draw support from the reverse logistics network of electrical and electronic products. This is also the reason why we carry out a specific study on the reverse logistics network model of electrical and electronic products.

\section{Overview of Reverse Logistics}

To complete this article with high quality, first of all we need to understand reverse logistics. Tab. 1 visualizes the characteristics of reverse logistics. From this table, we can gain a deep insight into reverse logistics.

Tab. 1 Characteristics of Reverse Logistics

\begin{tabular}{cllll}
\hline Characteristic & Uncertainty & Direction & Benefit & Economy of Scale \\
\hline Characteristic & Difficult to predict & Reverse & Social benefit goal & Hard to achieve \\
& Complex & Hybrid & Speed & Handling charge \\
\hline Characteristic & More complex & High hybridity & Slow & High \\
& Single price & Pricing & Handling mode & Marketing mode \\
\hline Characteristic & Non-single & Inconsistent & Ambiguous & $\begin{array}{l}\text { Complex } \\
\text { diverse }\end{array}$ \\
& & and
\end{tabular}

With a simple knowledge of the characteristics of reverse logistics, we also need to clarify the driving factors of reverse logistics. Tab. 2 visualizes these driving factors. From this table, we can learn about the genesis of a reverse logistics network model of electrical and electronic products more intuitively and deeply [1].

Tab. 2 Driving Factors of Reverse Logistics

\begin{tabular}{lc}
\hline Driving Factor & Manifestation \\
\hline Environmental Stress & $\begin{array}{c}\text { A large amount of waste of electrical and electronic products tends to become e-waste due to } \\
\text { improper disposal. The national environment will undergo great pressure and threats; } \\
\text { Simple disposal of the waste of electrical and electronic products often results in the depletion of } \\
\text { Resource Depletion } \\
\begin{array}{c}\text { Policies } \\
\text { Regulations }\end{array} \\
\text { and } \\
\text { Economic Interests } \\
\text { With ever-increasing national and public environmental consciousness, the unveiling of various } \\
\text { policies and regulations will gradually put the disposal of waste of electrical and electronic products } \\
\text { in China on the right track. } \\
\text { The recycling of waste of electrical and electronic products can reduce production costs and cut } \\
\text { down material consumption. Accordingly, economic interests will emerge; }\end{array}$ \\
\hline
\end{tabular}




\section{Foreign Reverse Logistics Networks of Electrical and Electronic Products}

With a simple knowledge of reverse logistics, we also need to analyze foreign reverse logistics networks of electrical and electronic products in depth. Tab. 3 visualizes 5 common foreign reverse logistics networks of electrical and electronic products. From this table, we can gain a deep insight into the reverse logistics networks of electrical and electronic products.

Tab. 3 Five Common Foreign Reverse Logistics Networks of Electrical and Electronic Products

\begin{tabular}{|c|c|}
\hline $\begin{array}{l}\text { Reverse Logistics Network of } \\
\text { Electrical and Electronic Products }\end{array}$ & Characteristic \\
\hline MDCM & $\begin{array}{l}\text { The manufacturer is the subject, which directly contacts consumers } \\
\text { and realizes the recycling of old electrical and electronic products; }\end{array}$ \\
\hline MDCDM & $\begin{array}{l}\text { The manufacturer is the subject, which recycles old electrical and } \\
\text { electronic products through sales channels; }\end{array}$ \\
\hline MDCTM & $\begin{array}{l}\text { A third-party reverse logistics service provider is the subject, who } \\
\text { delivers old products to the manufacturer after basic treatment; }\end{array}$ \\
\hline MCM & $\begin{array}{l}\text { The manufacturer is the subject, which recycles old electrical and } \\
\text { electronic products through direct sales; }\end{array}$ \\
\hline МСТM & $\begin{array}{l}\text { Based on direct sales, this mode belongs to a recycling mode under an } \\
\text { open-loop supply chain. }\end{array}$ \\
\hline
\end{tabular}

With a simple knowledge of 5 common foreign reverse logistics networks of electrical and electronic products, we also need to understand the manifestations of these models in actual applications. Fig. 1 shows a reverse logistics network of electrical and electronic products in Georgia, the United States. From this figure, we can find out that in this model, the waste of electrical and electronic products is divided into two categories. Commercial consumers undertake all recycling fees [2].

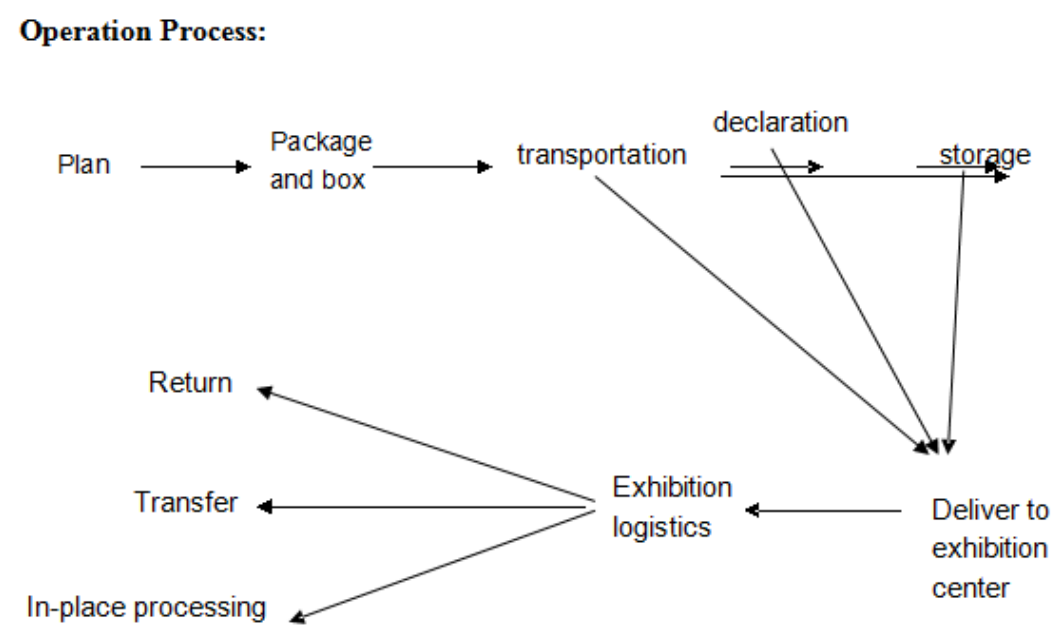

Fig. 1 A Reverse Logistics Network of Electrical and Electronic Products in Georgia, the United States

Japan, however, implements a reverse logistics network of electrical and electronic products as shown in Tab. 4. Combining Fig. 1 with Tab. 4, it is not hard to find that government support and consciousness of large-scale enterprises play a huge role in the reverse logistics network model of electrical and electronic products. But it is quite difficult to popularize this model in China.

Tab. 4 A Reverse Logistics Network of Electrical and Electronic Products in Japan

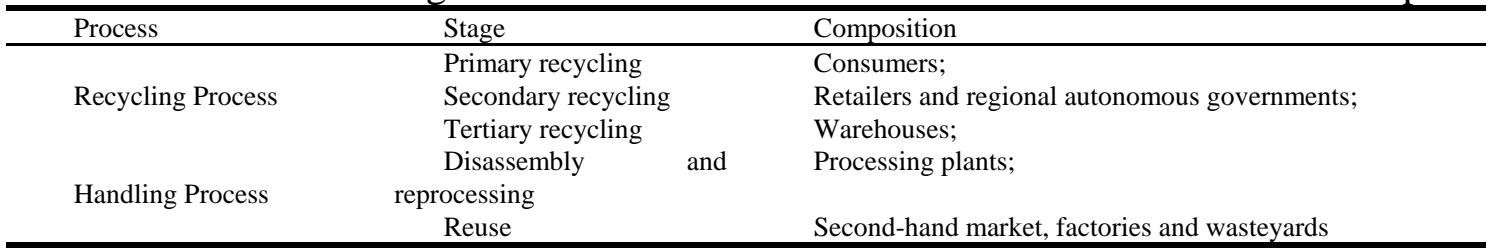




\section{The Building of a Domestic Reverse Logistics Network Model of Electrical and Electronic Products}

From the above, we gain a deep insight into the reverse logistics network of electrical and electronic products. On this basis, the author identifies principles to build a domestic reverse logistics network of electrical and electronic products, i.e., environmental protection, sustainable development, legislation, integration, industrialization, marketization, closed-loop system and product life cycle. In combination with these principles, the author builds a domestic reverse logistics network model of electrical and electronic products, as shown in Tab. 5.

Tab. 5 A Domestic Reverse Logistics Network Model of Electrical and Electronic Products

\begin{tabular}{|c|c|c|}
\hline Process & Stage & Content \\
\hline \multirow{3}{*}{ Recycling Process } & Primary recycling & $\begin{array}{c}\text { Consumers, community committees, street vendors and } \\
\text { distributors are subjects that play a role in this stage; }\end{array}$ \\
\hline & Secondary recycling & $\begin{array}{l}\text { Municipal departments and vendors receive electrical and } \\
\text { electronic products; }\end{array}$ \\
\hline & Tertiary recycling & $\begin{array}{l}\text { Electrical and electronic products are classified according to } \\
\text { product life cycle; }\end{array}$ \\
\hline \multirow{3}{*}{ Handling Process } & Reprocessing & $\begin{array}{l}\text { Electrical and electronic products flow into the market again } \\
\text { through maintenance, modification and reprocessing; }\end{array}$ \\
\hline & & Available spare parts are sold. Raw materials are processed. \\
\hline & Disassembly & $\begin{array}{l}\text { Finally, hazardous substances and waste are sent to wasteyards. This } \\
\text { process must focus on nonhazardous treatment. }\end{array}$ \\
\hline
\end{tabular}

\section{Conclusion}

In the present study on the reverse logistics network model of electrical and electronic products, the author elaborates on concepts related to reverse logistics, foreign reverse logistics networks of electrical and electronic products and the building of a domestic reverse logistics network of electrical and electronic products. From these, we can gain a deep insight into the reverse logistics network of electrical and electronic products. Hopefully, this paper could bring some inspiration to the building of a resource-conserving and environment-friendly society in China.

\section{References}

[1]Salema M I G, Barbosa-Povoa A P, Novais A Q. An optimization model for the design of a capacitated multi-product reverse logistics network with uncertainty[J]. European Journal of Operational Research, 2007, 179(3):1063-1077.

[2]Alumur S A, Nickel S, Saldanha-Da-Gama F, et al. Multi-period reverse logistics network design[J]. European Journal of Operational Research, 2012, 220(1):67-78. 